\title{
Individual and Environmental Risk Factors of Tuberculosis: A New Evidence from Ponorogo, East Java
}

\author{
Diana Sayidah'), Setyo Sri Rahardjo²), Bhisma Murti1) \\ 1)Masters Program in Public Health, Universitas Sebelas Maret \\ ${ }^{2)}$ Faculty of Medicine, Universitas Sebelas Maret
}

\begin{abstract}
Background: For centuries, TB has been linked anecdotally with environmental risk factors that go hand-in-hand with poverty: indoor air pollution, tobacco smoke, malnutrition, overcrowded living conditions, and excessive alcohol use. But to date, there is no empirical evidence from East Java, Indonesia, to support these anecdotal evidences. The purpose of this study was to provide new evidence on the individual and environmental risk factors of tuberculosis in Ponorogo, East Java.

Subjects and Method: A case control study was conducted in Ponorogo, East Java, from April to May 2018. A sample of 200 study subjects was selected for this study by fixed disease sampling. The dependent variable was tuberculosis. The independent variables were age, gender, education, nutritional status, dwelling density, smoking, and alcohol drinking. Data on tuberculosis infection status were obtained from the medical record at District Health Office Ponorogo. The data were collected by questionnaire and analyzed by a multiple logistic regression on Stata 13 .

Results: Age $\geq 44$ years $(b=3.18 ; 95 \% \mathrm{CI}=1.66$ to $4.69 ; \mathrm{p}<0.001)$, nutritional status $(\mathrm{b}=1.42 ; 95 \%$ $\mathrm{CI}=0.02$ to $2.82 ; \mathrm{p}=0.046)$, dwelling density $\geq 5(\mathrm{~b}=1.87 ; 95 \% \mathrm{CI}=0.37$ to $3.36 ; \mathrm{p}=0.014)$, smoking ( $b=2.23 ; 95 \% \mathrm{CI}=0.61$ to $3.85 ; \mathrm{p}=0.007)$, and alcohol drinking $(\mathrm{b}=2.83 ; 95 \% \mathrm{CI}=1.38$ to 4.27; $\mathrm{p}<0.001)$ were associated with increased risk of tuberculosis. Higher education $(\mathrm{b}=-2.56$; 95\% $\mathrm{CI}=-4.16$ to $-0.96 ; \mathrm{p}=0.002)$ and female $(\mathrm{b}=-1.36 ; 95 \% \mathrm{CI}=-2.92$ to $-0.20 ; \mathrm{p}=0.087)$ were associated with decreased risk of tuberculosis.

Conclusion: Age, nutritional status, dwelling density, smoking, alcohol drinking, education, and female, are shown in this study to be the risk factors of tuberculosis.
\end{abstract}

Keywords: tuberculosis, individual factor, environmental factor

\section{Correspondence:}

Diana Sayidah. Masters Program in Public Health, Universitas Sebelas Maret, Jl. Ir. Sutami No. 36 A, Surakarta 57126, Central Java. Email: dianasayidah13@gmail.com.

Mobile: +6282234721294 .

\begin{abstract}
BACKGROUND
Tuberculosis (TB) is one of the major infectious diseases that cause death in cases of tuberculosis with HIV comorbidities (Fogel, 2015). Tuberculosis is among the top 10 diseases that cause deaths in the world with 1.4 million deaths annually. By 2015, there are 10.4 million new cases of tuberculosis in the world, with 5.9 million (59\%) male, 3.5 million (34\%) female and there are 1 million (10\%) children, of which 1.2 million
\end{abstract}

(11\%) of them are tuberculous patients (WHO, 2016).

About $60 \%$ of cases are from India, Indonesia, China, Nigeria, Pakistan and Africa (WHO, 2016). Prosser et al. (2016) mentions that one-third of the world's population has been infected with tuberculosis with Asia as the world's highest spread of tuberculosis.

The highest incidence of tuberculosis in 2015 came from Southeast Asia of 45.6\% of the world's population with Indonesia 
Journal of Epidemiology and Public Health (2018), 3(3): 353-360

https://doi.org/10.26911/jepublichealth.2018.03.03.06

ranked 2 of 11 countries after India (23\%) with the percentage of Indonesia (10\%) of 1020 cases per 1000 population as countries with highest tuberculosis disease burden (WHO, 2016).

TB is affected by several risk factors such as age, sex, education, occupation, nutritional status (Fogel, 2015, WHO, 2016) as well as occupancy density, shelter lighting (Zumla et al., 2016), alcohol consumption and smoking (Rao et al., 2018).

Data on TB cases in Indonesia in 2016 were 156,723 and in East Java were 21,606. TB in East Java was ranked second after West Java (Ministry of Health, 2016). In the Ponorogo region, TB cases amounted to 810 (Profile of Health Office, Ponorogo, 2016) and for the Ponorogo region it-self with the category of poor families of 266,312 (Profile of BPS, 2016).

Based on preliminary study conducted in Ponorogo district, in Jambon subdistrict, there are 37 people with diagnosis of TB, in Sawo sub-district, there are 63 people with TB diagnosis, in Balong subdistrict, there are 52 people with TB diagnosis, and in Ngrayun sub-district, there are 93 people with diagnosis of TB, Slahung subdistrict, there are 65 . This study examines the determinants of Tuberculosis risk factors both biologically included age, sex, and nutritional status. The social economy is education, smoking and alcohol consumption. And the environment is the dwelling density. Based on the problem, the researcher is interested to take the title of Tuberculosis Risk Factor Proposal in Ponorogo Regency Year 2018.

\footnotetext{
SUBJECTS AND METHOD

1. Study Design

This was an analytic observational study with a case control design. The study was conducted in Ponorogo, East Java, from April to May 2018.
}

\section{Population and Samples}

The source population was divided into two which are patients with tuberculosis and those without tuberculosis. A sample of 200 study subjects was selected by fixed disease sampling.

\section{Study Variables}

The dependent variable was tuberculosis. The independent variables were age, sex, education, nutritional status, dwelling density, smoking, and alcohol consumption.

\section{Operational Definition of Variables}

Tuberculosis was defined as a patient diagnosed with TB based on anamnesis, physical examination, smear positive, and photo thorax. The data were collected by medical record. The measurement scale was categorical.

Age was defined as the age of the study subjects when first diagnosed with TB. The data were collected by questionnaire. The measurement scale was continuous.

Gender was defined as the sex of TB patient. The data were collected by questionnaire. The measurement scale was categorical, coded o for female and 1 for male.

Education was defined as the ultimate education of TB patients. Education levels tend to influence attitudes, behaviors, knowledge and insights because everything is necessary because of its connection with infectious diseases (TB). The data were collected by questionnaire. The measurement scale was categorical, coded $\mathrm{o}$ for $<$ senior high school and 1 for $\geq$ senior high school.

Nutritional status was defined as the nutritional state of the study subjects measured by body mass index (BMI) prior to diagnosis of TB. Individual nutritional status affects the risk of TB. The data were collected by questionnaire. The measurement scale was continuous, transformed 
into dichotomous, coded o for $<25$ and 1 for $\geq 25$.

Residential density was defined as the residential condition of the study subject which were densely populated or not densely populated. Densely populated areas tend to have shabby dwellings, poor hygiene of areas that are not proportional to the number of occupants will make it unhealthy because beside it causes a lack of oxygen consumption so that when there are members affected by infectious diseases, especially TB will be easily transmitted to other members and will acelerate the process of spreading.

Smoking was defined as the study subject of a typical study of active or passive smokers before being diagnosed by TB. Smoking is an unhealthy habit of potentially damaging the airway not to mention the link with lungs. Smoking destroys the cilia or fine hairs in the throat, this cilia function as the first defense when there is a germ incoming cilia damaged germs which can enter easily into the lungs.

Alcohol was defined as the study subject consuming alcohol status before TB diagnosed. Alcohol disrupts protein levels that are present outside the lung tissue, the condition will shorten the protective function of the antioxidants affect the immune system's resistance and trigger a condition. Alcohol harms the pulmonary molecules and triggers the onset of serious illness (TB).

\section{Data Analysis}

Univariate analysis was done to see the frequency distribution and percentage characteristics of study subjects. The bivariate analysis was done to study the relationship between tuberculosis with the independent variables using chi-square test and odds ratio calculation (OR) with confidence level (CI) of 95\%. The multivariate analysis was done using logistic regression.

\section{Research Ethics}

The research ethics include informed consent, anonymity, confidentiality, and ethical clearance. The ethical clearance in this study was conducted in Dr. Moewardi hospital, Surakarta.

\begin{tabular}{lcc}
\hline \multicolumn{3}{c}{ RESULTS } \\
\hline 1. Study Subject characteristics \\
Table 1. Study subject characteristics \\
\hline \multicolumn{2}{c}{ Variable } & n \\
\hline Gender & & \\
Male & 135 & 67.5 \\
Female & 65 & 32.5 \\
Education & & \\
Low (<senior high school) & 99 & 49.5 \\
High ( $\geq$ senior high school) & 101 & 50.5 \\
Age & & \\
< 44 years old & 114 & 57.0 \\
$\geq 44$ years old & 86 & 43.0 \\
Occupation & & \\
Working at home & 107 & 53.5 \\
Working outside & 93 & 46.5 \\
Smoking & & \\
No & 100 & 50.0 \\
Smoking & 100 & 50.0 \\
Alcohol & & \\
No & 132 & 66.0 \\
Alcohol & 68 & 34.0 \\
Dwelling density & & \\
Not dense & 102 & 51.0 \\
Dense & 98 & 49 \\
Body Mass Index & & \\
$\geq 18.5$ & 147 & 73.5 \\
< 18.5 & 53 & 26.5 \\
\hline
\end{tabular}

A sample of 200 study subjects comprising 50 patients with $\mathrm{TB}$ and 150 patients without TB. The frequency distribution of study characteristics were described in Table 1.

Table 1 shows that most of the study subjects were male 135 (67.5\%), $\geq$ senior high school (101, 50.5\%), working at house $(107,53.5 \%)$, did not consume alcohol (132, $66 \%$ ), and IMT $\geq 18.5$ (143, 73.5\%). Half of study subjects were smoker (100, 50.0\%).

\section{Bivariate Analysis}

The bivariate analysis was used to observe age, sex, education, nutritional status, 
Journal of Epidemiology and Public Health (2018), 3(3): 353-360

https://doi.org/10.26911/jepublichealth.2018.03.03.06

occupancy density, smoking and alcohol consumption with the incidence of tuber- culosis. The result of bivariate analysis can be seen in table 2 .

Table 2. Bivariate Analysis of Tuberculosis Risk Factors

\begin{tabular}{|c|c|c|c|c|c|c|c|c|c|}
\hline \multirow{3}{*}{ Variable } & \multicolumn{4}{|c|}{ Tuberculosis } & \multirow{2}{*}{\multicolumn{2}{|c|}{ Total }} & \multirow{3}{*}{$\mathbf{O R}$} & \multirow{3}{*}{$95 \% \mathrm{CI}$} & \multirow{3}{*}{$\mathbf{p}$} \\
\hline & \multicolumn{2}{|c|}{ No } & \multicolumn{2}{|c|}{ Yes } & & & & & \\
\hline & $\mathbf{n}$ & \% & $\mathbf{n}$ & $\%$ & $\mathbf{N}$ & $\%$ & & & \\
\hline \multicolumn{10}{|l|}{ Gender } \\
\hline Male & 92 & 68.1 & 43 & 31.9 & 135 & 100 & \multirow[t]{2}{*}{0.23} & 0.11 to & \multirow{2}{*}{0.001} \\
\hline Female & 58 & 89.2 & 7 & 10.8 & 65 & 100 & & 0.61 & \\
\hline \multicolumn{10}{|l|}{ Education } \\
\hline$<$ senior high school & 55 & 55.6 & 44 & 44.4 & 99 & 100 & \multirow[t]{2}{*}{0.79} & 0.32 to & \multirow{2}{*}{$<0.001$} \\
\hline $\begin{array}{l}\geq \text { senior high school } \\
\text { Age }\end{array}$ & 95 & 94.1 & 6 & $5 \cdot 9$ & 101 & 100 & & 1.97 & \\
\hline$<44$ years old & 107 & 93.9 & 7 & 6.1 & 114 & 100 & \multirow{3}{*}{38.5} & 16.91 to & \multirow{2}{*}{$<0.001$} \\
\hline$\geq 44$ years old & 43 & 50.0 & 43 & 50.0 & 86 & 100 & & 87.56 & \\
\hline \multicolumn{9}{|l|}{ Smoking } & \\
\hline No & 89 & 89.0 & 11 & 11.0 & 100 & 100 & \multirow[t]{3}{*}{5.17} & 2.46 to & \multirow[t]{2}{*}{$<0.001$} \\
\hline Yes & 61 & 61.0 & 39 & 39.0 & 100 & 100 & & 10.89 & \\
\hline \multicolumn{9}{|l|}{ Alcohol } & \\
\hline No & 124 & 93.9 & 8 & 6.1 & 132 & 100 & \multirow[t]{2}{*}{25.03} & 10.51 to & \multirow[t]{2}{*}{$<0.001$} \\
\hline Yes & 26 & 38.2 & 42 & 61.8 & 68 & 100 & & 59.54 & \\
\hline \multicolumn{10}{|l|}{ Dwelling Density } \\
\hline Not Dense & 96 & 94.1 & 6 & $5 \cdot 9$ & 107 & 100 & \multirow[t]{2}{*}{13.04} & 5.22 to & \multirow[t]{2}{*}{$<0.001$} \\
\hline Dense & 54 & 55.1 & 44 & 44.9 & 93 & 100 & & 32.58 & \\
\hline \multicolumn{10}{|l|}{ BMI } \\
\hline$<18.5$ & 100 & 98.0 & 2 & 2.0 & 102 & 100 & 48.00 & 11.21 to & $<0.001$ \\
\hline$\geq 18.5$ & 50 & 51.0 & 48 & 49.0 & 98 & 100 & & 205.5 & \\
\hline
\end{tabular}

Table 3. The results of a multiple logistic regression

\begin{tabular}{lcccc}
\hline \multirow{2}{*}{ Independent variables } & \multirow{2}{*}{$\mathbf{b}$} & \multicolumn{2}{c}{$\mathbf{9 5 \%}$ CI } & \multirow{2}{*}{ p } \\
\cline { 3 - 4 } & & Lower limit & Upper limit & \\
\hline Male gender & -1.36 & -2.92 & -0.20 & 0.087 \\
Age $\geq$ 44 years & 3.18 & 1.66 & 4.69 & $<0.001$ \\
High family income & -2.56 & -4.16 & -0.96 & 0.002 \\
Education $\geq$ senior high school & 1.42 & 0.52 & 8.55 & 0.027 \\
BMI $<18.5$ & 3.06 & 0.02 & 2.82 & 0.046 \\
Dwelling density & 1.87 & 0.37 & 3.36 & 0.014 \\
Smoking & 2.23 & 0.61 & 3.85 & 0.007 \\
Consumption of Alcohol & 2.83 & 1.38 & 4.27 & $<0.001$ \\
\hline
\end{tabular}

\section{Multivariate Analysis}

Multivariate analysis described the effect of more than one independent variables to one dependent variable. The method used was logistic regression by using STATA 13 progam.

Table 3 showed that the risk of TB was negatively affected by male gender $(\mathrm{b}=$ $-1.36 ; 95 \% \mathrm{CI}=-2.92$ to $-0.20 ; \mathrm{p}=0.087$ ) and high family income $(\mathrm{b}=-2.56 ; 95 \% \mathrm{CI}=$ -4.16 to $-0.96 ; \mathrm{p}=0.002$ ).

The risk of TB was positively affected by age $\geq 44$ years old $(b=3.18 ; 95 \% \mathrm{CI}=1.66$ to $4.69 ; \mathrm{p}<0.001)$, education $\geq$ senior high school $(\mathrm{b}=1.42 ; 95 \% \mathrm{CI}=0.52$ to $8.55 ; \mathrm{p}=$ 0.027), BMI <18.5 (b=3.06; 95\% CI=0.02 to $2.82 ; \mathrm{p}=0.046$ ), high dwelling density $(b=1.87 ; 95 \% \mathrm{CI}=0.37$ to $3.36 ; \mathrm{p}=0.014)$, smoking $(\mathrm{b}=2.23$; $95 \% \mathrm{CI}=0.61$ to $3.85 ; \mathrm{p}=$ 
0.007), and consuming alcohol $(b=2.83$; $95 \% \mathrm{CI}=1.38$ to $4.27 ; \mathrm{p}<0.001)$.

\section{DISCUSSIONS}

1. The relationship between age and tuberculosis

The result of this study showed that there was a positive association between age and tuberculosis. Age $\geq 44$ years old were more likely to have tuberculosis. Young et al. (2015) explained that physiological function of the body decrease at age $>60$ years. Along with the enhancement of age, atherosclerosis and macroangiopathy disorder can occur and it affected the decrease of blood circulation and lead to the occurrence of diseases such as diabetes mellitus and hypertension.

The 15-55 years old age group was an age group that has very high mobility, so the possibility of the exposure to Microbacterium Pulmonary Tuberculosis was greater, and the endogenous reactive (reactive in the body) could occur at the older age (Woimo et al., 2017).

Proses et al. (2016) stated that with the occurrence of tuberculosis at an older age, it can resulted in side effects obtained by the treatment of tuberculosis with more severe physical effects which can lead to disruption of work and can affect the social role of patients so that it affected the income and the quality of life of patients with tuberculosis.

\section{The relationship between educa- tion and tuberculosis}

The result of the study showed that there was a significant effect between education and tuberculosis. Marra et al., (2014) explained that high level of education has an effect on someone's quality of life because of his/ her knowledge related to transmitted diseases such as tuberculosis.

High level of education affected the awareness of each individual and better insight into various diseases so that someone was able to detect the symptoms early and provide appropriate follow-up (Woimo et al., 2017).

The exposure of tuberculosis virus due to many related aspects such as the lack of knowledge about tuberculosis and the prevention of the disease, in addition, the negative social stigma related to tuberculosis disease caused the patients who have tuberculosis to not immediately checked themselves because of bad stigma related to tuberculosis. The lack of knowledge about the disease, tuberculosis treatment process, and the presence of adverse reactions (drug side effects) in most tuberculosis patients have an impact on the occurrence of tuberculosis treatment resistance (Hoza et al., 2015).

\section{The relationship between nutritio- nal status and tuberculosis}

The result of the study showed that there was a significant effect between nutritional status and tuberculosis. Nutritional factors could affect a person to be infected to the diseases, one of them was tuberculosis (Narasimhan et al., 2013).

Less nutrition would cause a low endurance so that the defense against TB germs would be reduced. Lack of nutriational status was due to low socioeconomic conditions. Nutrition was needed in the process of repairing tissues and preventing diseases.

Lack of nutrition lead to weak immunity, thus increasing the occurrence of TB (WHO, 2013). In addition, poor body immunity of patients would lead to more severe disease or became resistant to the tuberculosis drugs (Sun et al., 2017).

\section{The relationship between dwelling density and tuberculosis}

The result of the study showed that there was a significant effect between dwelling density and tuberculosis. Dwelling density 
was one of the determinant factors of tuberculosis, dense dwelling has higher risk to the occurrence of tuberculosis.

The density of the house members could also affected health, because a dense house might allow the transmission of disease from one human to another. The excessive density of residents in the room would affect the development of the disease in the room (Babu et al., 2012).

Resident density was one of the factors that could increase the incidence of pulmonary tuberculosis and other transmitted diseases. A house with more than 2 family members who lived in a room with a minimum size of $9 \mathrm{~m}^{2}$ was stated as a dense house. Therefore, the number of family member in the house should be adjusted to the width of the house in order to avoid excessive density (Ambaw et al., 2015).

\section{The relationship between smoking and tuberculosis}

The result of the study showed that there was a significant effect between smoking and tuberculosis. Smokers were more likely to have tuberculosis.

This was in line with the previous study which stated that smoking has an effect on tuberculosis, in addition, the level of education has a great effect on smoking behavior. With high level of education, it was expected that someone has an awareness of the smoking dangers for him/ herself and others (Silva et al., 2017).

Based on the results of this study, it showed that most of the subjects who experienced tuberculosis have low education. From the results of the study by Pärna et al. (2014), it was known that smoking activity among men and women with higher education tend to decrease.

\section{The relationship between alcohol and tuberculosis}

The result of the study showed that there was a significant effect between alcohol consumption and tuberculosis. The habit of drinking alcohol would affect a person's habits or behavior to smoke (Pedroet al., 2017).

This was in line with the previous study which stated that alcohol consumption was one predisposition for the occurrence of tuberculosis disease because someone who consumed alcohol would have an impact on the decline of the immune system so that when she/ he exposed to the $\mathrm{TB}$ virus, the body was not able to provide protection (Zhang et al., 2017). Based on a study by Skrahina et al. (2013), it was stated that alcohol abuse and alcohol use disorders were known to have arole in TB development as well as the result of TB treatment.

Based on the results of this study, there was a relationship between age ( $\geq 44$ years old), male gender, low education, abnormal nutritional status, dwelling density $\geq 5$ peoples, smoking, and consumption of alcohol with tuberculosis.

\section{REFERENCES}

Ambaw F, Mayston R, Hanlon C and Alem A. (2015). Determinants, Course and Impact on Pathways to Care and Treatment Outcomes in a Primary Care Setting in Southern Ethiopia a Study Protocol. BMJ Open, 5: 1-10.

Anyim LD, Alduendae JL, Velarde HV, Cruz AT, Ergara HF, Mendoza DM and Sancho CG. (2014). Comparison of Bacteriological Conversion and Treatment Outcomes among MDR-TB Patients with and Without Diabetes in Mexico: Preliminary Data. Rev Port Pneumol, 23(1): 27-30.

Babu RG and Laxminarayan R. (2012). The Unsurprising Story of MDR-TB Resistance in India. Tuberculosis, 92: 301-306. 
Blaser N, Zahnd C, Hermans S, Vizcaya LS, Estill J, Morrow C, Egger M. (2016). Tuberculosis in Cape Town: an AgeStructured Transmission Model. Epidemics, 14.54-61.

Dotulong JFJ, Sapulete MR, Kandou GD. (2015). Hubungan Faktor Risiko Umur, Jenis Kelamin dan Kepadatan Hunian dengan Kejadian Penyakit Tb Paru di Desa Wori Kecamatan Wori. Jurnal Komunitas Kedokteran dan Tropik, 3 (2).

Fogel Z, Napiorkowska A, Kaminski M, Kopec EA, Zwolska Z, Bielecki J, Jagielski T.(2015). Second-line Antituberculosis Drug Resistance and its Genetic Determinants in Multidrugresistant Mycobacterium Tuberculosis Clinical Isolates. Journal of Microbiology, Immunology and Infection. 49: 439-444.

Hoza AS, Sayoki GM, Mfinanga SGM and Onig BK. (2015). Anti-TB Drug Resistance in Tanga, Tanzania: A Cross sectional Facility-base Prevalence Among Pulmonary TB Patients. Asian Pacific Journal of Tropical Medicine, 8(11): 907-913.

Kapur A, Harries AD (2013). The Double Burden of Diabetes and Tuberculosis Public Health Implications. Diabetes Researchand Clinical Practical, 1: 1019.

Kemenkes RI (2016). Profil Kesehatan Indonesia tahun 2015. Jakarta: Kemenkes RI.

Ma E, Ren L, Wang W, Takahashi H, Wagatsuma Y, Ren Y, Gao F et al. (2014). Demographic and Socioeconomic Disparity in Knowledge About Tuberculosis in Inner Mongolia, China. Journal of Epidemiology, 25(4): 312320.
Narasimhan WHO. (2013). Guideline: Nutritional Care and Support for Patients with Tuberculosis.

Prosser G, Brandenburg J, Reiling N, Barry CE, Wilkinson RJ and Wilkinson KA. (2016). The Bacillary and Macrophage Response to Hypoxia in Tuberculosis and the Consequences for $\mathrm{T}$ Cell Antigen Recognition. Microbes and Infection.1-16.

Parna K, Purjer ML, Ringmets I and Tekkel M. (2014). Educational Differences in Cigarette Smoking Among Adult Population in Estonia, 1990-2010: Does The Trend Fit The Model of Tobacco Epidemic?. BMC Public Health, 14(709): 1-8.

Silva RD, de Luna FDT, de Araujo AJ, Camelo ELS, Bertolozzi MR, Hino P, Lacerda SNB et al. (2017). Patients' Perception Regarding The Influence of Individual and Social Vulnerabilities on The Adherence to Tuberculosis Treatment: A Qualitative Study. BMC public health, 17(725): 1-9.

Rao VG, et al. (2017). Smoking And Alcohol Consumption: Risk Factors For Pulmonary Tuberculosis Among The Tribal Communits in Central India. Indian Journal of Tuberculosis, 64: 40-43.

Theron G, Peter J, Zijenah L, Chanda D, Mangu C, Clowes P, Rachow A et al. (2015). Psychological Distress and its Relationship with Non-Adherence to TB Treatment: a Multicentre Study. BMC Infectious Diseases, 13-19.

Umanah TA, Ncayiyana JR and Nyasulua PS. (2015). Predictors of Cure Among HIV Co-Infected Multidrug-Resistant TB Patients at Sizwe Tropical Disease Hospital Johannesburg, South Africa. Trans R Soc Trop Med Hyg, 109: 340-348. 
Journal of Epidemiology and Public Health (2018), 3(3): 353-360

https://doi.org/10.26911/jepublichealth.2018.03.03.06

World Health Organization (2016). Global Tuberculosis Report 2016. Geneva: WHO Press.

Young, F, Critchley JA, Johnstone LK and Unwin NC. (2009). Globalization And Health a Review of Co-Morbidity Between Infectious and Chronic Disease in Sub Saharan Africa: TB and Diabetes Mellitus, HIV and Metabolic Syndrome, and the Impact of Globalization. BMC Public Health, 9: $1-9$.
Zhang C, Wang Y, Shi G, Han W, Zhao H, Zhang $\mathrm{H}$ and Xi X. (2017). Determinants of Multidrug-Resistant Tuberculosis in Henan Province in China: A Case Control Study. BMC Public Health, 16(42): 1-9.

Zumla E, Ghose B, Vaibhav S and Michael E. (2017). Socioeconomic Disparities in Smoking Behavior and Early Smoking Initiation Among Men in Malawi. Tobacco Use Insights, 10: 1-7. 